(RESEARCH ARTICLE)

\title{
Stable amylaze-produsing micromycetes isolated from soils of South Caucasus
}

\author{
Khvedelidze R.M. ${ }^{*}$, Kutateladze L.I., Tsiklauri N.D., Zakariashvili N.G. and Aleksidze T.I. \\ Durmishidze Institute of Biochemistry and Biotechnology, Agricultural University of Georgia, Tbilisi, Georgia.
}

Publication history: Received on 18 August 2018; revised on 26 September 2018; accepted on 01 October 2018

Article DOI: https://doi.org/10.30574/gscbps.2018.5.1.0086

\begin{abstract}
Production of stable enzymes is one of the actual problems in bio- and enzyme technology. Conducting of the fermentation processes at pasteurization temperature is of great importance (2800 strains) because of making possible to minimize pollution of the reaction medium. Collection of micellar fungi isolated from different ecological niches of the Caucasus has been created in Durmishidze Institute of Biochemistry and Biotechnology. 39 strains - producers of amylase were revealed in the collection as a result of screening. Most of these strains belong to the genus Aspergillus. The temperature optimum of thermophilic strains was studied. In the cultural liquids obtained after the submerged cultivation of selected strains $\alpha$-amylase producers were tested in the temperature range $30-45^{\circ} \mathrm{C}$, at $5{ }^{\circ} \mathrm{C}$ intervals. The temperature optimum of the strains was established to be within the range $65-70{ }^{\circ} \mathrm{C}$, making possible to use them in bio- and enzymatic technologies to diminish the pollution of the reaction medium while conducting the fermentation process at pasteurization temperature $\left(65^{\circ} \mathrm{C}\right)$. Consequently, the selection of stable, operable at pasteurization and higher temperatures amylase preparation is of great importance. Proposed technology is cost-effective, ecologically safe, competitive and provides deep hydrolysis of starch to fermentable sugar at the elevated temperature (65-70 ${ }^{\circ} \mathrm{C}$ ) in one step, by means of only one, stable amylase preparation.
\end{abstract}

Keywords: $\alpha$-amylase; Aspergillus; Thermophilic strains; Fermentation; Enzymes

\section{Introduction}

Production of enzymes preparations is one of the leading branches in modern biotechnology and belongs to constantly growing areas of industry with extend application of spheres, in spite of even the crisis phenomena in the world economy. Enzymatic biotechnologies should be considered as low power-consuming, waste less, and ecologically harmless with low risk level processes. The basic problems of application enzymes in the industry are high cost and low stability of the great majority of commercial enzymes far not always satisfying the requirements of industrial processes [1-3]. Latest achievements in molecular biology, genetic and protein engineering, allow the creation of qualitatively new generations of microbial enzymes. Often, enzymes of genetically modified microorganisms, characterized by the improved properties, undoubtedly expand potential for their industrial application. In particular, the stability of commercial preparations of cellulases, xylanases, amylases, lipases, proteases, does not correspond to the industrial requirements. Related to cellulase research, besides comparatively low enzyme yield, there are some critical challenges such as: low heat stability and specific activity [4-6]. Low stability of enzymes remains as one of the main limiting factors for their wide and more effective application. Selection of microorganisms for last two, three decades has proved that stable forms of enzymes are more expedient to search among microorganisms possessing optimum growth at unusual conditions [7-9]. Development of biological disciplines over the recent years, conducting of several researches in the areas of molecular biology, molecular genetics and genetic engineering have required to create new microbial collections. The existing and new collections allow possibility to detect the industrial purpose strains, which will be used for creation of precious metabolites of microbial origin. Detection and receiving of microbial origin enzyme preparations is especially important. Receiving of enzyme preparations occupies one of the leading positions in modern

\footnotetext{
${ }^{*}$ Corresponding author

E-mail address: r.khvedelidze@agruni.edu.ge
} 
biotechnology and belongs to those branches of industry whose production volume is permanently growing and the areas of application are expanding. Hydrolytic enzymes - cellulases, xylanases, amylases, proteases, inulinases, lipases, composing more than $80 \%$ of all enzymes used in industry, due to their application potential in different brunches of industry, medicine and agriculture are of great interest. Availability of stable forms of these enzymes would not only expand area of their application, but also reduce the price of products produced by the use of these enzymes. Among the microbial enzymes, important enzyme usable in food and light industries is amylase [10-12]. Heat stable amylases, active at $65{ }^{\circ} \mathrm{C}$, undoubtedly, will find application in production of alcohol, glucose-fructose syrup, and in other technologies, where stability of enzymes, in many respects, defines sterility and efficiency of entire process. Receiving of the high activity amylase enzyme preparations is possible by detection of the active amylase producers from the strains existing in the collection of microorganisms. During the last 10 years, selection of microorganisms has clearly demonstrated that the searching for stable forms of enzymes is appropriate mainly among those microorganisms that exist within the relatively critical conditions [13-15]. Existence of active, genetically stable fungi strains, with appropriate extracellular activities of $\alpha$-amylases, differing in their relation to reaction mixture, creates a good opportunities for their effective use in different branches of food processing.

\section{Material and methods}

Screening of strains active amylase producers was hold in submerged cultures. Conidial suspension of 10-12 days cultures served as inocula. Cultivation was conducted in $750 \mathrm{ml}$ Erlenmeyer flasks, on temperature-controlled shaker $(160-220 \mathrm{rev} / \mathrm{min})$ at $30^{\circ} \mathrm{C}$, for 72 hours. In order to obtain amylases, in deep cultivation was carried out in a liquid medium supplemented with \%: starch - 6.0; $\mathrm{NaNO}_{3}-0.91 ; \mathrm{KH}_{2} \mathrm{PO}_{4}-0.1 ; \mathrm{MgSO}_{4} \times 7 \mathrm{H}_{2} \mathrm{O}-0.05, \mathrm{KCl}-0.05, \mathrm{FeSO}-0.0002$, malt extract- $1.5 \mathrm{ml}$ per $50 \mathrm{ml}$ [16-17]. After cultivation, the culture solution was centrifuged at $4000 \mathrm{rpm}$. In the cultural liquids obtained after the submerged cultivation the amylase activity was studied.

Determination of $\alpha$-amylase activity was based on decreased staining value of blue starch-iodine complex [18-19]. Glucoamylaze activity was determined with respect of glucose. The concentration of free glucose was assayed, using a glucooxidase reagent after 10 min hydrolysis.

To obtain enzymatic preparations, filtrate of culture liquid was centrifuged at $4000 \mathrm{rpm}$ and cooled to $+4^{\circ} \mathrm{C}$. Ethyl alcohol (1/4) was added to cold enzyme solution under the conditions of gradual stirring. After 20-30 min formed pellet was removed by centrifugation (4000 rpm for 10 minutes) and lyophilized [20-21].

\section{Results and discussion}

At Durmishidze Institute of Biochemistry and Biotechnology, Georgian Agrarian University, is created a collection of micellar fungi, isolated from different ecological zones of Caucasus, accounting about 2500 strains of various taxonomic groups. Among this strains are producers of carbohydrolases - cellulases, amylases, proteases, xylanases. As a result of screening our collection 39 strains producing amylases were selected with different degree of $\alpha$ - and glucoamylase activities. Most of them belong to the genus Aspergillus .

Application of amylases ( $\alpha$ - and glucoamylases) is an obligatory tecnological operation in the production of glucosefructose syrup from starch containing substrates (wheat, corn, potato, maize, buckwheat peas, etc.). Stability of enzyme preparetion determines sterility and effectiveness of the whole process. Consequently, the selection of stable, operable at pasteurization and higher temperatures amylase preparation is of great importance. Proposed technology is costeffective, ecologically safe, competitive and provides deep hydrolysis of starch to fermentable sugar at the elevated temperature $\left(65-70^{\circ} \mathrm{C}\right)$ in one step, by means of only one, stable amylase preparation. Sugar yield from starch much depends on the type of amylases and their activities. This feature will largely determine enzyme loading and duration of hydrolysis, which in turn determines overall process economics. We have selected most active producers with both $\alpha$ - and glucoamylase activities. 


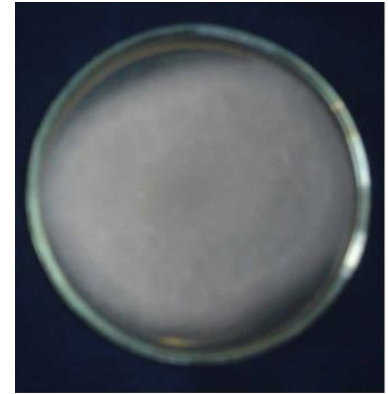

Mucor

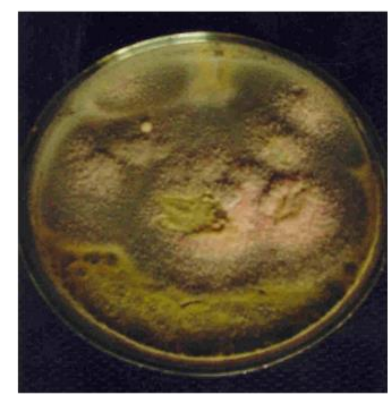

Botritis

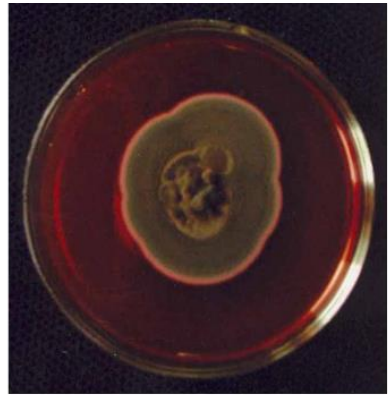

Penicillium

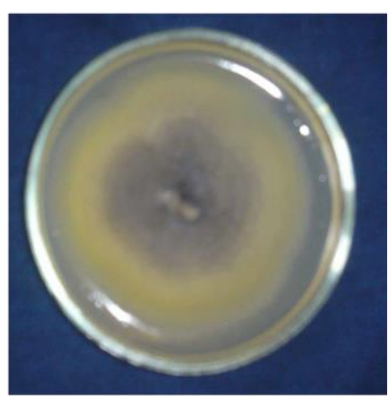

Absidia

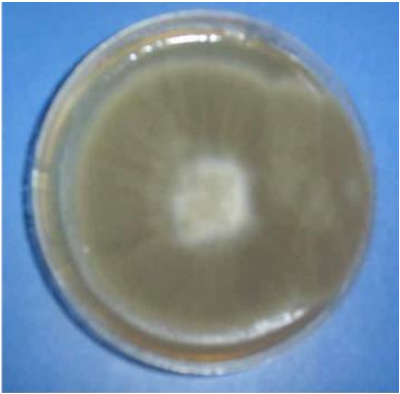

Rhizopus

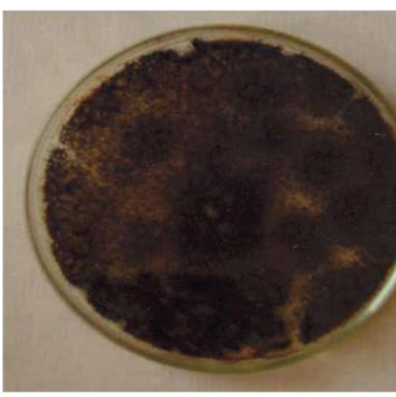

Aspergillus niger

Figure 1 Amylase producers of different genera

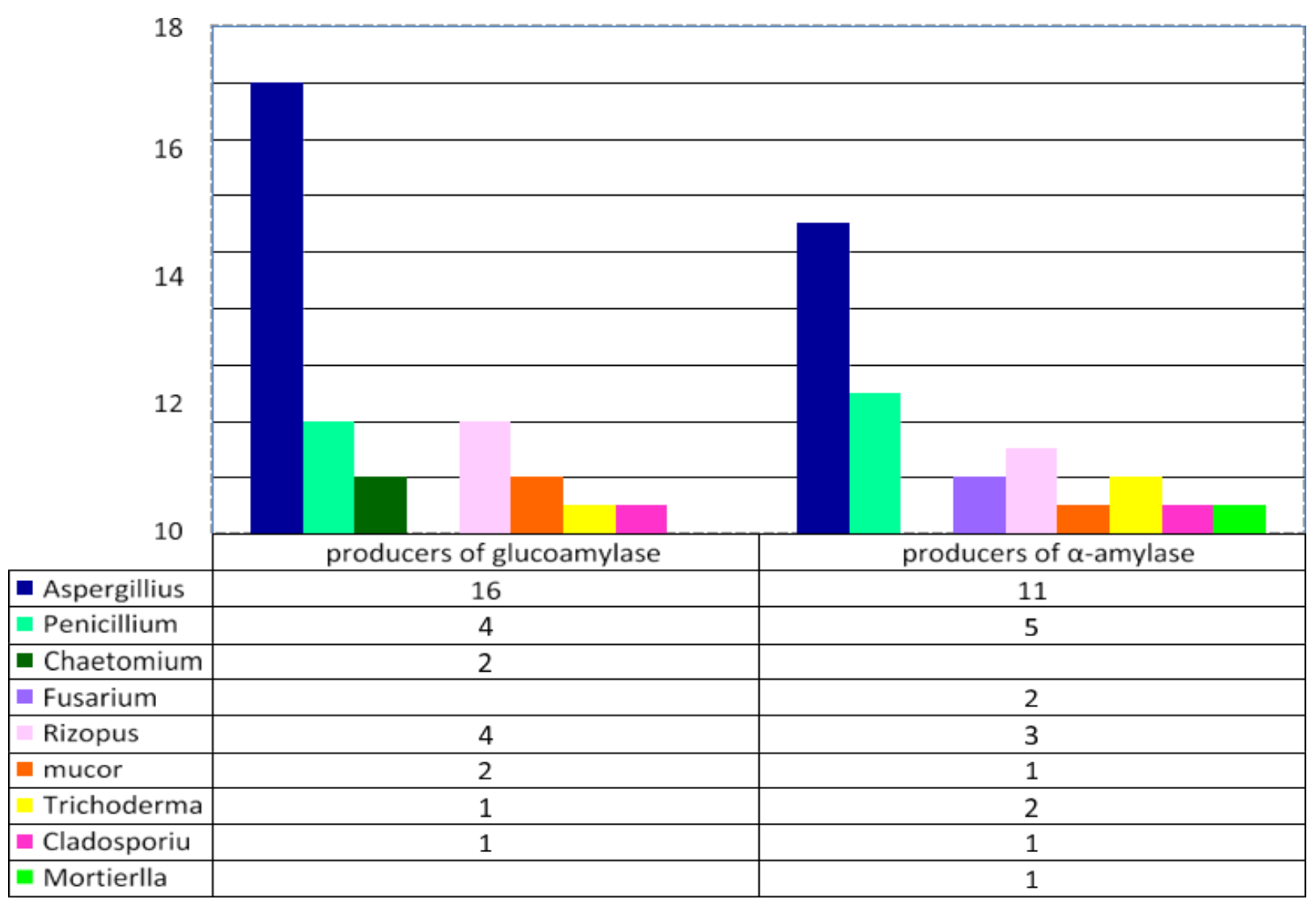

Figure 2 Microscopic fungi strains - producers of amylolitic enzymes 
Table 1 Extracellular $\alpha$-amylase and glucoamylase activities of selected strains

\begin{tabular}{lll}
\hline Strain & $\begin{array}{l}\boldsymbol{\alpha} \text {-Amylase } \\
\mathbf{U} / \mathbf{m l}\end{array}$ & $\begin{array}{l}\text { Glucoamylase } \\
\mathbf{U} / \mathbf{m l}\end{array}$ \\
\hline Aspergillus niger P8-3 & 0.67 & 40.5 \\
Aspergillus niger B6 & 0.45 & 22.6 \\
Aspergillus awamori S16 & 0.60 & 12.5 \\
Aspergillus niger ch-26 & 0.65 & 35.8 \\
Aspergillus oryzae BS 27 & 0.55 & 30 \\
Mucor sp. T 37 & 0.42 & 8.5 \\
Rhizopus sp. S 75 & 0.55 & 9.2 \\
Penicillium sp. S 80 & 0.8 & 11.6 \\
Penicillium sp.T 52 & 0.52 & 7.2 \\
Mortierella sp. S 34 & 0.67 & 12.3 \\
\hline
\end{tabular}

As much as temperature is extremely important in microorganism growth regulation and physiological activity, at first the effect of temperature on the enzyme production was studied. Taking into consideration the optimum growth temperature for enzyme active producers, their submerged cultivation was performed at $20-40^{\circ} \mathrm{C}$. Aspergillus oryzae BS 27 was found to reveal high $\alpha$-amylase and glucoamylase activity at $30^{\circ} \mathrm{C}$, the culture of Aspergillus nigerch-26 and Aspergillus niger $p 8-3$ at $35^{\circ} \mathrm{C}$ (Figure 3 and 4 ).

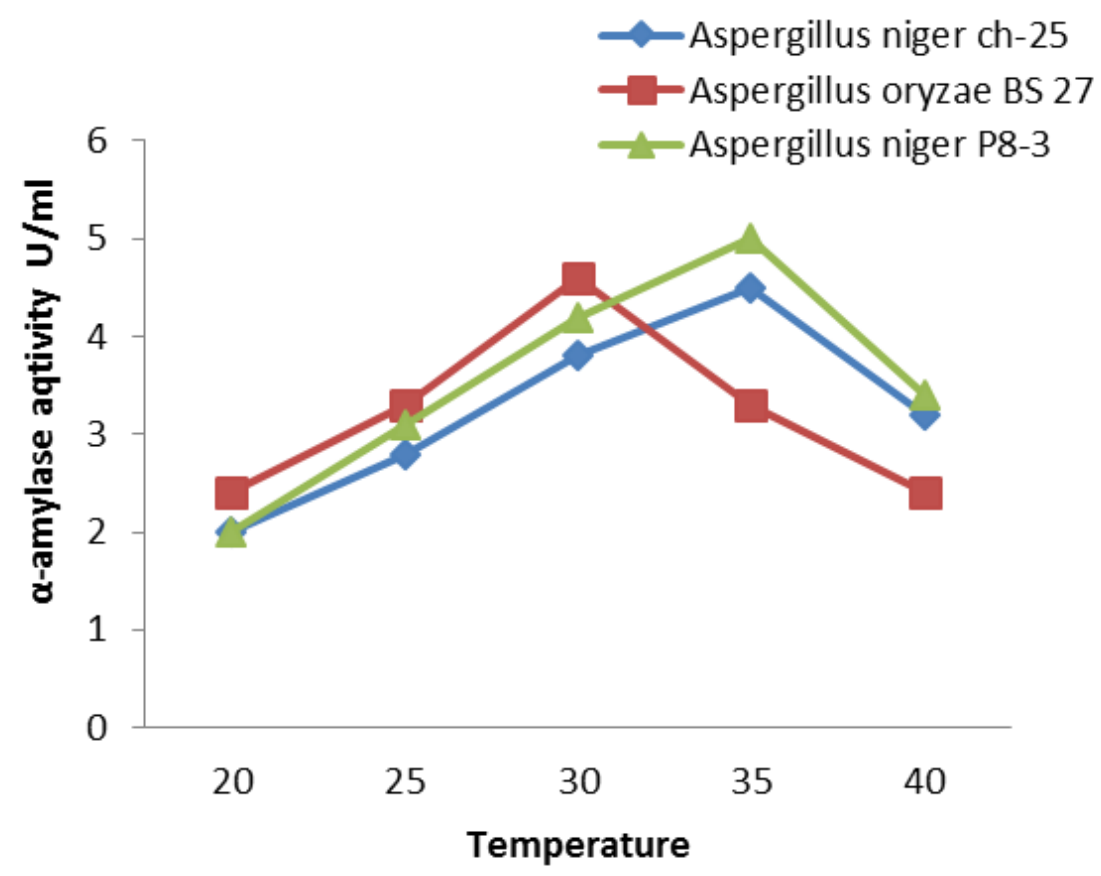

Figure $3 \alpha$-amylase activity 


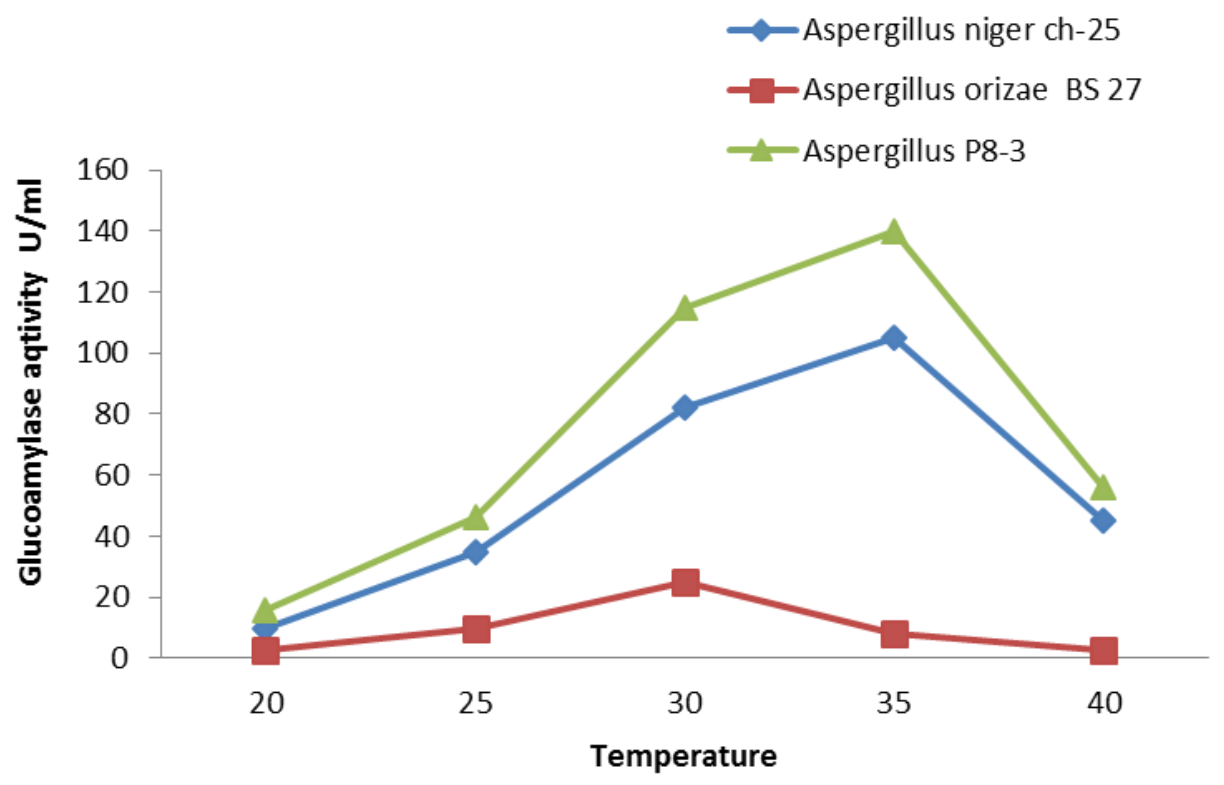

Figure 4 Glucoamylase activity

Conducting of the fermentation processes at pasteurization temperature $\left(65^{\circ} \mathrm{C}\right)$ is of great importance as it minimized pollution of the reaction medium. Reviling the strains of amylase producers, which retain activity at high temperature, is perspective for solving this problem. To determine temperature optimums of activity for amylases, enzymatic activity was measured between $30-80^{\circ} \mathrm{C}$, by $5^{\circ} \mathrm{C}$ temperature interval. Optimal temperatures of action of amylases from three producers were established to be within the range $67-70{ }^{\circ} \mathrm{C}$. A. oryzae showed higher $\alpha$-amylase and glucoamylase activity at $40^{\circ} \mathrm{C}, A$. niger ch-26 and A. niger p8-3 showed higher $\alpha$-amylase and glucoamylase activity at $70{ }^{\circ} \mathrm{C}$ (Figure 5 and 6).

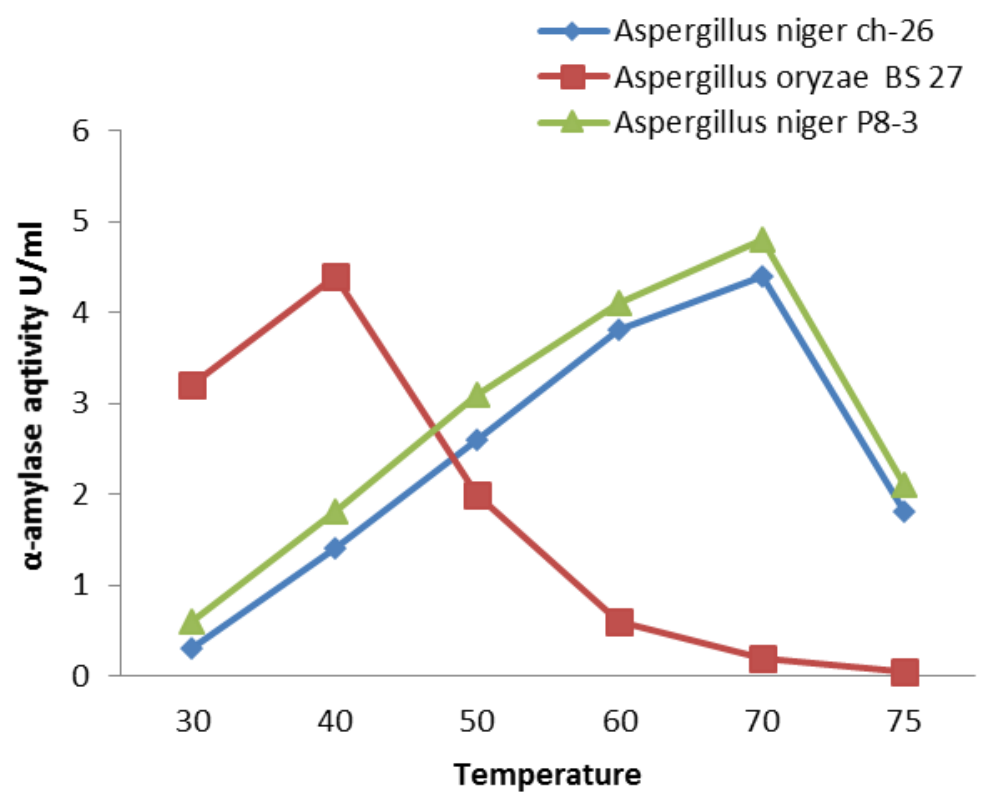

Figure $5 \alpha$-amylase activities of Aspergillus strains within the range of $30-75^{\circ} \mathrm{C}$ 


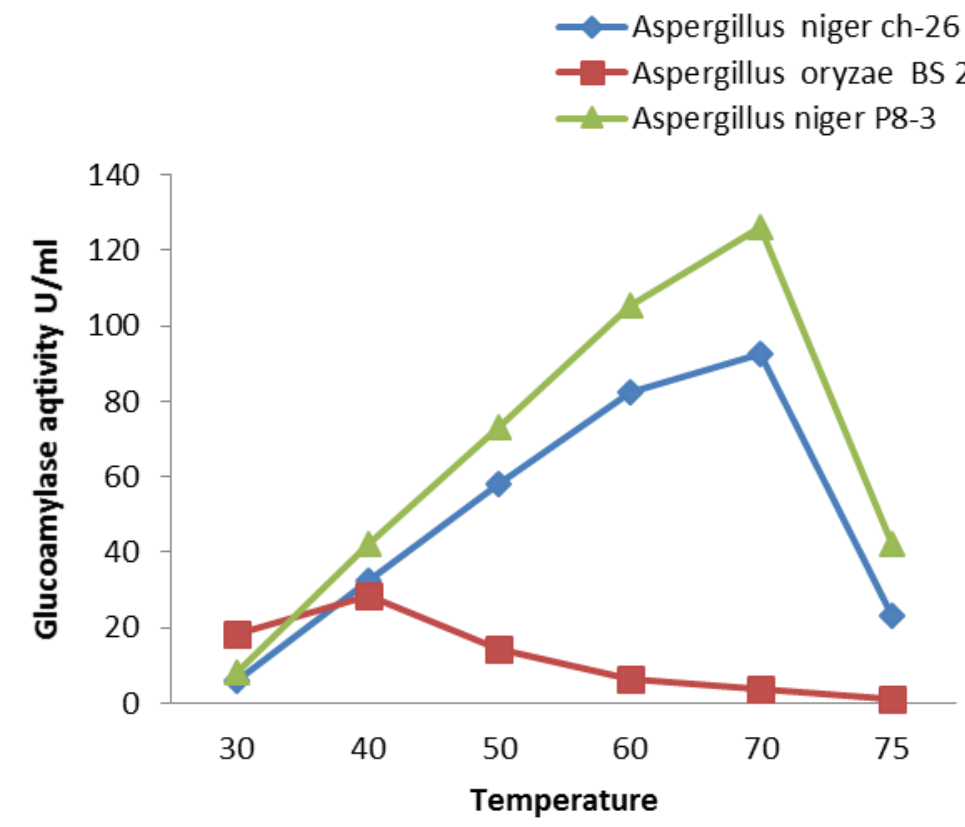

Figure 6 Glucoamylase activities of Aspergillus strains within the range of $30-75^{\circ} \mathrm{C}$.

Selection of microorganisms for last two, three decades has proved that stable forms of enzymes are more expedient to searche among the microorganisms possessing optimum growth at unusual conditions [22] In order to obtain stable enzymes of micromicetes, cultivation of producers under extreme conditions attracts peculiar interest. Not all enzymes, formed by extremophiles have increased stability in comparison with their mesophiles analogues. However, there are quite a few examples that some enzymes produced by fungi extremophiles, do not require additional stabilization [23]. Large amounts of patents, original publications, reviews and monographs are devoted to the ways of application of hydrolytic enzymes. In 2007, "Springer" has published the reviews devoted to the manufacture and application of enzymes. Peculiar interest attracts the material devoted to industrial enzymes [24] in which the separate chapters are devoted to the application of enzymes in food processing and other branches of industry and in agriculture. Traditionally, amylases of fungal and bacterial origin have been long time used in different branches of food processing. First of all it is application of $\alpha$-amylase and glucoamylase in starch hydrolysis (wheat, corn, potato, etc.) to fermenting sugars [10]. Amylases is an important technological operation in brewing industry.

\section{Conclusion}

Collection of micellar fungi isolated from different ecological niches of South Caucasus has been created in Durmishidze Institute of Biochemistry and Biotechnology. As a result of screening among collection strains 39 producers of amylase were selected with different degree of $\alpha$ and glucoamylase activities. Most of them belong to the genus Aspergillus. The temperature optimum of growth of enzyme active producers, their submerged cultivation was performed within 20-40 ${ }^{\circ} \mathrm{C}$. Aspergillus oryzae BS 27 was found to reveal high $\alpha$-amylase and glucoamylase activity at $30{ }^{\circ} \mathrm{C}$, the culture of Aspergillus nigerch-26 and Aspergillus niger p8-3 at $35^{\circ} \mathrm{C}$. Optimal temperatures of action of amylases from three producers were established to be within the range $67-70^{\circ} \mathrm{C}$. A.oryzae showed the highest $\alpha$-amylase and glucoamylase activity at $40{ }^{\circ} \mathrm{C}$, A.niger ch-26 and A.niger p8-3 showed the highest $\alpha$-amylase and glucoamylase activity at $70{ }^{\circ} \mathrm{C}$. Detailed analysis of $\alpha$-amylases and glucoamylase of mold origin has revealed the existence of two types of enzymes. Regular $\alpha$-amylase and glucoamylase from mesophilic yellow-green fungi with the optimum of action temperature 40 ${ }^{\circ} \mathrm{C}$ Aspergillus oryzae BS 27; Heat-stable $\alpha$-amylase and glucoamylase from thermophilic fungi, with the optimum of action above $70{ }^{\circ} \mathrm{C}$ Aspergillus nigerch-26 and Aspergillus niger p8-3. As a result of exhausted hydrolysis of different types of starch form fermentable sugars: glucose, maltose and maltotriose (maltotetrose in trace amounts). Existence of active, genetically stable fungi strains, with appropriate extracellular activities of $\alpha$-amylases and glucoamylase, differing in their relation to reaction mixture, creates a good opportunities for their effective use in different branches of food processing. 


\section{Compliance with ethical standards}

\section{Disclosure of conflict of interest}

The authors declare that there is no conflict of interest.

\section{References}

[1] Kvesitadze GI. (1990), Enzymes of Microorganisms Living under Extreme Conditions [in Russian], Ed. W. Kretovich, Nauka, Moscow, 52.

[2] Fernandes P. (2010). Enzymes in food processing: a condensed overview on strategies for better biocatalysts. Enzyme research, 2010.

[3] Gupta A, Gupta VK, Modi DR and Yadava LP. (2008). Production and characterization of $\alpha$-amylase from Aspergillus niger. Biotechnology, 7(3), 551-556.

[4] Vorontsova N, Goncharova O and Kvesitadze GI. (1991). “Applied Biochemistra and Microbiology” 17, (4), 569573.

[5] Acourene S and Ammouche A. (2012). Optimization of ethanol, citric acid, and $\alpha$-amylase production from date wastes by strains of Saccharomyces cerevisiae, Aspergillus niger, and Candida guilliermondii. Journal of industrial microbiology \& biotechnology, 39(5), 759-766.

[6] Saxena RK, Dutt K, Agarwal L and Nayyar P. (2007). A highly thermostable and alkaline amylase from a Bacillus sp. PN5. Bioresource Technology, 98(2), 260-265.

[7] Maheshwari R, Bharadwaj G and Bhat MK. (2000). Thermophilic fungi: their physiology and enzymes. Microbiology and molecular biology reviews, 64(3), 461-488.

[8] Das S, Sing S, Sharma V and Soni M. (2011). Biotechnological applications of industrially important amylase enzyme. International Journal of Pharma and Bio Sciences, 2(1), 5.

[9] Adejumo A, Agboola F and Lauokun S. (2009). Hydrolysis of maize starch using amylolytic enzymes extracted from sorghum malt. Int. J. Biol. Chem. Sci., 3(5), 1030-1041.

[10] Aquino A, Jorje J, Terenzi H and Polizeli M. (2003). Studies on a thermostable $\alpha$-amylase from the thrmophilic fungus, Scytalidium thermophilum. Applied microbiology and biotechnology, 61(4), 323-328.

[11] Liu X and Kokare C. (2017). Microbial enzymes of use in industry. In Biotechnology of Microbial Enzymes, 267298.

[12] Pritchard P. (2002). Studies on the bread improving mechanisms of fungal amylase. Journal of Biological Education, 26, 12-18.

[13] Vorontsova N, Kvesitadze GI and Kvesitadze E (2006). Amilolitic enzymes and their application in alcohol indastry. Moscow, (in Russian), 3(4), 87-123.

[14] Saranraj P and Stella D. (2013). Fungal amylase-A review. International Journal of Microbiological Research, 4(2), 203-211.

[15] Liu XD and Xu Y. (2008). A novel raw starch digesting $\alpha$-amylase from a newly isolated Bacillus sp. YX-1: purification and characterization. Bioresource Technology, 99(10), 4315-4320.

[16] Kathiresan K and Manivannan S. (2006). -Amylase production by Penicillium fellutanum isolated from mangrove rhizosphere soil. African journal of Biotechnology, 5(10).

[17] Sundarram A, Pandurangappa T and Murthy K. (2014). $\alpha$-Amylase production and application. Journal of Applied \& Environmental Microbiology, 2(4), 166-175.

[18] Kvesitadze GI, Kvesitadze E. (1999) Biotechnology, Tbilisi, „Ertrat”, (in Georgian)

[19] Haki G and Rakshit S. (2003). Developments in industrially important thermostable enzymes: a review. Bioresource Technology, 89(1), 117-134.

[20] Pandey A, Nigam P, Soccol C, Soccol V, Singh D and Mohan R. (2000). Advances in microbial amylases. Biotechnology and Applied Biochemistry, 31, 135-152. 
[21] Uthumporn U, Zaidul S and Karim A. (2010). Hydrolysis of granular starch at sub-gelatinization temperature using a mixture of amylolytic enzymes. Food and Bioproducts Processing, 88, 47-54.

[22] Maheshwari R, Bharadwaj G and Bhat MK. (2007). ADV Biochem Engin/Biotechnol Industrial enzymes, 105: 59131.

[23] Haki G and Rakshet S. (2003). Development of industrially important thermostable enzymes a review. Bioresourse Technology, 89, 17-34.

[24] Satyanarayana T, Ragbukumar C and Sbiraji S. (2005). Extremophilic Microbes: Diversity and perspectives. Current Science, 89(1), 45-62.

\section{How to cite this article}

Khvedelidze RM, Kutateladze LI, Tsiklauri ND, Zakariashvili NG and Aleksidze TI. (2018). Stable amylaze-produsing micromycetes isolated from soils of South Caucasus. GSC Biological and Pharmaceutical Sciences, 5(1), 119-126. 